\title{
UTILIZATION OF THE DIRECT AND INDIRECT SPEECH ACT OF ASSERTION BY THE SENTENCE TYPES Samir Jamal Ibraheem
}

\begin{abstract}
:
Tackling any text, e.g. political one, without pragmatic theory constitutes a real problem in the communicative act. the need to shed light on distinctive rules concerning the speech act of assertion is crucial. So this study is concerned with how to establish a model of expressing the speech act of assertion, whether direct or indirect, by using the sentence types of declarative, interrogative, or imperative sentences. Since this utilization highly overlaps with other speech acts as command, obligation, permission, ability, etc. Therefore, this research attempts to answer the following questions:
\end{abstract}

1- Can this study formulate a model for analysing the speech act of assertion, and on which bases it can be established?

2- How to formulate Felicity conditions for the speech act of assertion?

3- Whether speech act of assertion can be successfully applied to political speeches?

4- Which sentence type can typically express the direct speech act of assertion?

5- Could other sentence types indicate the speech act of assertion?

\section{CHAPTER ONE:}

\section{Pragmatic Overview}

Assertionis a pragmatic conceptinthe sense that a speaker uses language, in communication, to assertwhat he knows or believes to be true, i.e. he uses language to present information as true.

\subsection{Assertion in Speech Act Theory}

Crystal (2003: 427) definesspeechact as a term derived from the work of Austin (1911-1960) to refer to a theory which analyses the role of utterances in relation to the behaviour of speaker and hearer in interpersonal communication.

Pagin (2007: 1-3) sees assertion as a speech act in which something is claimed to hold. He adds that assertionisapropositional act in that it relates the speaker to a proposition, or is an act with propositional content. 


\subsection{Austin's Speech Act Theory}

Austin (1911-1960) is the founding father of the general theory of speech act..InAustin's initial work with speech act theory he divides utterances into two types: performatives and constatives (Huang, 2007: 94-5). Performatives are utterances that are used to do things or perform acts, whereas Constatives are utterances that are employed to makeassertions or statements.

Austin abandons the constatives/ performatives distinction, he concludes that all utterances contain both constatives and performatives elements: they are saying and doing at the same time. He replaces it with a distinction of three types of acts: locution, illocution and perlocution:(Verschuren, 1999: 22).

1- The locutionary act: is the basic act of utterance, or producing a meaningful linguistic expression (Yule, 1996: 48).

2- The illocutionary act: isthe making of statement, assertion, offer, promise, etc., in uttering a sentence, by virtue of the conventionalforce associated with it (or with its explicit performative paraphrase). (Levinson, 1983: 236; Schiffer, 2002: 90).Accordingly, when an assertion is made the utterance has an assertive force.

3-Theperlocutionaryact: is the act made to have an effect on the hearer as a consequence of the illocutionary act. For instance, It is the perlocutionary act only in a case that the hearer is affected by the speaker's utterance and the hearer, then, changes his knowledge about the man's status (Van Dijk, 1977: 198-9).

Furthermore, Austin [(1962: 150-164), as cited in Horn and Warq (2004: 64)], comes up with further classification of illocutionary acts (or illocutionary verbs) which are realized via five general classes of performative verbs:Verdictives, Exercitives, Commisives, Behabitives and Expositives.

In Austin's classification, assertion would be best placed under expositive, since the prefix 'I assert'is of an expository nature. Expositive is defined as acts of expounding of views, conducting of arguments, and clarifying of usages and references, e.g. deny, inform, concede, refer, etc.

\subsection{Searle's Speech Act Theory}

The philosopher John. R Searle is the first who proposes an extensive formulation of the Austin's theory. Searle (1969: 33-42) draws attention to the constitutive rules. He (1971: 40) statesthat "to perform illocutionary acts is to engage in a rule-governed form of 
behaviour."Searle also modifies Austin's felicity conditions. He argues that to perform a speech act is to obey certain conventional rules that are constitutive of that type of act which he calls constitutive rules - rules that create the activity itself- of speech acts (Huang, 2007: 104).

-He identifies four basic categories, namely:

1- Propositional contents: are concerned with what the speech act is about. The simplest type of propositional content is expressed by means of acts of referring and predicating, where in a speaker refers to something and then characterizes it, for instance, when a speaker utters the sentence:

1. Agassi is tired.

He thereby 'asserts' that 'Agassi is tired'. In making this assertion, the speaker is also performing the propositional acts of referring to 'Agassi ' with the name Agassi and of characterizing him with the predicate is tired (Akmajianetal., 2001: 397).

2- Preparatory conditions : state the real-world prerequisites for the speech act. These conditions differ accordingly to different speech acts, for examples, promise, request, assertion, etc. These conditions for assertion are that the speaker has evidence for the truth of what he says and that it is not obvious to either that the hearer knows the facts (Palmer, 1981: 165).

3- Sincerity conditions: the act must be performed sincerely. These conditions for an assertion are different from those for a promise or a request. The conditions for an assertion involve that the speaker believes what he says (ibid).

4- Essential conditions: define the essential nature of speech act, for instance, in making a statement (assertion), a speaker must intend it to be taken as true (Cruse, 2006: 62-3).

Besides, Horn and Warq (2004: 61) add that essential conditions for assertion count as an under taking that $\mathrm{P}$ (proposition) represents an actual state of affairs.

Searle (1979: 2-8) distinguishes between illocutionary acts which are a part of language and illocutionary verbs which are always part of a particular language: English, German, French, etc. In Searle's taxonomy of illocutionary acts, he identifies twelve dimensions of illocutionary acts, but he uses, as cited in Mey (1993:163) only four of them . Huang (2007) summarized the illocutionary act of assertion as follows: 
Table (1): The Summary of the Illocutionary Act of Assertion

\begin{tabular}{|c|c|c|c|}
\hline $\begin{array}{c}\text { Illocutionary } \\
\text { Point }\end{array}$ & $\begin{array}{c}\text { direction of } \\
\text { fit }\end{array}$ & $\begin{array}{c}\text { expressed } \\
\text { psychological state }\end{array}$ & $\begin{array}{c}\text { Propositional } \\
\text { content }\end{array}$ \\
\hline Assertive & words-to-world & belief (speaker) & $\begin{array}{c}\text { Any proposition } \\
\text { expressed and } \\
\text { referred to in the } \\
\text { context of } \\
\text { utterance }\end{array}$ \\
\hline
\end{tabular}

(Huang, 2007: 108)

Searle, as cited in Cruse $(2000,342-3)$, discusses another classification concerning the illocutionary verbs (especially the performative verbs) in which he tries to relate it to Austin's classification, they are: Directives, Commissives, Expressives, Declaratives and Assertives (commit the speaker to the truth of the expressed proposition: state, suggest, boast, complain, claim, report, warn, etc.)(ibid). In using an 'Assertive', the speaker makes words fit the world (of belief).

\subsection{Pragmatic Situation of Speech Acts}

In order to analyse a speech act successfully (particularly, the speech act of assertion) it is necessary to study pragmaticsituations in which a speech act represents one aspect of these situations that determine the satisfactory explanation of meaning of an utterance.

Leech (1983: 13-4) defines pragmatics as the study of meaning in relation to speechsituations. He specifies five aspects of the speech situation as follows;

1- Addresser and addressee: Leech refers to addressers and addressees, as a matter of convenience, as $\mathrm{S}$ ('Speaker(s)/ writer(s)') and $\mathrm{H}$ ('Hearer(s)'/' 'reader(s)'). He clarifies the distinction between a receiver (a person who receives and interprets the massage) and an addressee (a person who is an intended receiver of the massage). So, when an addresser (speaker) asserts something in a particular context, a speaker intends his assertions to be received by the intended addressee (hearer) (ibid: 13).

2- Context of an utterance:

Leech refers to context to be any background knowledge assumed to be shared by $\mathrm{S}$ and $\mathrm{H}$ and which contributes to H's interpretation of what $\mathrm{S}$ means by a given utterance. The context of utterance plays the most 
important role in determining both direct and indirect speech act of assertion and distinguishing assertion from other speech acts such as, questioning, ordering, requesting, etc. (ibid: 13).

\section{3- Goal(s) of an utterance:}

This refers to a goal or function of an utterance. Leech would not prefer to use the term of intended meaning or S's intention in uttering it. But he prefers the term goal since it is more neutral than intention, because it does commit its user dealing with conscious volition or motivation. The speaker's goal in uttering a sentence/ clause must be aimed as an assertion (ibid).

4- The utterance as a form of act or activity:

grammar deals with abstract static entities such as sentences (in syntax) and proposition (in semantics), pragmatics deals with verbal acts or performances which take place in particular situations, in time. so, uttering a sentence as an assertion means that a speaker performs a certain kind of act in a particular context, which is the speech act of assertion, differs from acts such as, questioning, ordering, thanking, etc. (ibid: 14).

\section{5-The utterance as a product of a verbal act:}

Pragmatics deals with utterance meaning and semantics deals with sentence meaning. Hence, the semantic meaning of a declarative sentence is statement which asserts a proposition, whereas the pragmatic meaning of the utterance of a declarative sentenceis typicallyassertion (ibid).

What is not covered explicitly in Searle's taxonomy, as cited in Mey (1993: 163), is two conditions essential for a pragmatic understanding of a speech acting are (i) reference to a speaker or a hearer ('S', 'H') and (ii) contextual conditions (i.e. the framework in which a speech act has to be performed to be valid).

Therefore, these two conditions will be covered from what Leech has codified asaspects of the speech situation of pragmatics.

\subsection{Sentence types: Direct and Indirect Speech Acts}

The basic speech act concepts of assertion, questionanddirection are encoded in the grammar in the system of sentence/ clause types, respectively, of declarative, interrogative and imperative. When a sentence type is used to carry out the speech act typically and conventionally associated with it, it is consideredto be a direct speech act (Saeed, 1997: 206;Grundy, 2000: 58-9; Downing and Locke, 2006: 177). Hurford et al. (2007: 270) presents a table illustrating the sentence types and their typical linguistic functions. 
Table (2): Sentence type and its typical function

\begin{tabular}{|c|cc|}
\hline Sentence type & \multicolumn{2}{|c|}{$\begin{array}{c}\text { Typical linguistic act performed by uttering a } \\
\text { sentence of this type }\end{array}$} \\
\hline $\begin{array}{c}\text { declarative } \\
\text { interrogative } \\
\text { imperative }\end{array}$ & $\begin{array}{c}\text { assertion } \\
\text { questioning }\end{array}$ osking / \\
ordering / \\
\hline
\end{tabular}

In other words, in a direct speech act, the declarative sentence is said to have the illocutionary force of assertion.

Actually, in interpersonal interaction, every sentence type can carry out different speech acts and this can be considered as an indirect speech act. Accordingly, an assertion can be realized by other sentence types.

This fact is discussed and supported by Levinson (1983: 266) for example:

2. May I tell you that, I believe, the square root of a quarter is a half? (ibid).

3. Who cares? (Interrogative form functioning as an assertion $=$ no one cares)(Grundy, 2000: 59).

4. Let me tell you that, obviously, the square root of a quarter is a half (Levinson, 1983: 266).

The interrogative forms of (2), (3) and the imperative form of (4) have the illocutionary force of assertion (ibid).

On the contrary, declarative sentences can perform different speech acts, such as, questioning/ asking, requesting/ ordering, etc.

5. I wonder when the train leaves (Declarative sentence functioning asa question $=$ do you know when the train leaves, or a request $=$ tell me when the train leaves) (Grundy, 2000: 59).

6. (to a child) You'd better eat your dinner fast (Declarative sentence functioning as an order) (ibid).

\section{CHAPTER TWO:}

\section{Pragmatic Model}

This study sets up a pragmatic model in order to show how the speech act of assertion, direct and indirect, is to be analysed and manipulated through the use of the sentence types. This model depends mainly on Searle's theory of speech act, for direct and indirect speech act of assertion, supported by Leech (1983) speech situations especially the two points of (i) addresser and addres see and (ii) the context of utterance.

The pragmatic analysis involves the following two points (A) and (B). 


\section{(A) The Analysis for Direct Speech Act of assertion is going to be dealt with:}

1- In order to perform a successful direct speech act of assertion, in the sense that there is a direct match between a declarative sentence and the illocutionary force of assertion, Searle's felicity conditions must be fulfilled and carried out properly or felicitously in the situation. Searle's felicity conditions of speech act of assertion are discussed by Searle (1979: 62) and summarized by Horn and Warq (2004: 61) as follows:

- Propositional content: any proposition (p) expressed and referred to in the context of utterance.

- Preparatory condition: (i) speaker (S) has evidence (reasons, etc.) for the truth

of $\mathrm{P}$. (ii) It is not obvious to both $\mathrm{S}$ and $\mathrm{H}$ that $\mathrm{H}$ knows $\mathrm{P}$ (doesn't need to be reminded of, etc.).

- Sincerity condition: $\mathrm{S}$ believes $\mathrm{P}$.

- Essential condition: counts as an undertaking that $\mathrm{P}$ is true (represents an actual state of affairs).

When one of these conditions is violated or flouted, the speech act of assertion will not be performed properly or felicitously (i.e. infelicitous). Such violating or flouting implicates an indirect speech act of some other acts such as questioning, directing, requesting, ordering, etc.

(B) For Indirect Speech Act the analysis is following what is cited in Saeed (1997: 216) and Huang (2007: 112) namely:

The analysis assumes the existence of a dual illocutionary force. Searle proposes that indirect speech acts have two illocutionary forces, one literal or direct, and the other is non-literal or indirect. While the literal force is secondary, the non-literal force is primary. This means that performing the indirect (primary) illocutionary act of assertion entails that the direct (secondary) illocutionary act of another act is performed too (Huang, 2007: 112).

Both secondary and primary forces deal with the relevant felicity conditions. The indirect speech act of assertion is systematically related to the structure of the associated direct act, in the sense that the felicity conditions of the illocutionary act of assertion may be overlapping with the other direct illocutionary acts such as, questioning and directing made by, respectively, interrogative and imperative sentences (Saeed, 1997: 216).For this point, Hurfordet al. (2007: 285) assert that the context of situation identifies, for this study, the felicity conditions of the indirect (primary) illocutionary act of assertion to be held, whereas one, two or three, but not all, of the felicity conditions of the direct (secondary) illocutionary act of questioning and directing are deliberately infelicitous or in the other words, as Saeed 
(1997: 195) argues, they are flouted overtly by a speaker for some linguistic effect.

Finally, and in order to give an adequate and roughly a complete picture of analysis to the indirect speech act of assertion. Morgan (1978: 261-80) suggests the concept of conventionality. Searle [as cited in Huang (2007: 113)] comments that Searle proposes that there is a certain degree of conventionality about indirect speech acts, and this may be accounted for in terms of convention use /meaning. Therefore a sentence should have a certain degree of convention alusage to be more accepted in use as an indirect speech act of assertion.

\subsection{Assertion in Political Texts}

Recently, the focus is on the relationship between language and politics, so this study has chosen the political texts to shed light on the importance of such field, especially, in our current international political situation in the world. Hence,the adopted model of the speech act of assertion is going to be applied in political texts.

\section{Text (1)}

Barak Obama, a new beginning: speech at Cairo University, Cairo, Egypt, June 4, 2009 :

"Moreover, freedom in America is indivisible from the freedom to practice one's religion."

-Establishing the felicitous speech act of assertion:

1- Propositional content condition: Obama expresses his categorical assertion about the fact that freedom in America is inseparable from the freedom of practicing and worshiping any religion including, of course, Islam.

2- Preparatory condition: Obama asserts this plain fact due to the truth that Muslims in America do their religious ceremonies and rituals freely and without any obstruction. In addition, there is a Mosque in every state in America alongside with legal procedures protecting the right to wear hijab or veil in America.

Obama's categorical assertion is well-chosen in the context of utterance.

3- Sincerity condition: Obama definitely believes what he asserts.

4- Essential condition: It is true that Obama's utterance is counted to be as a categorical assertion in that Obama's assertion about religious freedom in America represents an actual state of affairs that everyone in every religion can practice its religious duties including the 7 million American Muslims.

-Pragmatic analysis

Concerning the pragmatic level, Obama at Cairo University in 2009 declares the categorical and plain assertion about the fact of the 
American freedom to practice religious ceremonies, referring to the 7 million American Muslims who have 1200 mosques in America and have the legality which protects their right and the women right to wear hijab and to punish those who would deny it. Obama uses explicitly the primary assertive verb 'is' to express that he has no doubt about his knowledge and belief of the American freedom(Macmilian, 1964: 10; Jespersen, 1968: 321). The primary verb 'is' within the declarative sentence uttered in a falling-tone, in this context, reveals the direct illocutionary force of assertion.'

\section{Text (2)}

George W. Bush, war message, Washington, DC, March 19, 2003:

"I know that the families of our military are praying that all those who serve will return safely and soon."

-Establishing the felicitous speech act of assertion:

1-Propositional content condition :Bush's assertion is expressed through his knowledge in the sense that he is categorically sure and has no doubt (psychological assertion) of the truth of the proposition that all American soldiers' families want their children return home safely.

2- Preparatory condition: Bush asserts this proposition that the addressees hope all their soldiers return home safely based on the evidence that all American families have the natural orientation of love towards their children. It is not obvious for Bush that his addressees do not want to be reminded of this fact, so what he reminds them is suitable in the context of utterance.

3- Sincerity condition: Bush definitely believes that all American families wish their children go back home safely soon.

4- Essential condition: Bush intends his utterance to be counted as a categorical assertion in the sense that the proposition that all American families are actually praying for their children to return home safely is true and represents an actual state of affairs in America.

\section{-Pragmatic analysis:}

Pragmatically, these lines are utilized by Bush to express the direct illocutionary force of assertion through the use of the declarative sentence which expresses Searle's 'assertive' of speech act by using an explicit assertive verb 'know' for declaring a clear truth. Bush asserts the proposition to the American citizens in the White house at the beginning of war against the Iraqi regime in 2003.The war is definitely dangerous, and causes death and wounds. Therefore, this truth is based on his knowledge that he knows and has no doubts that all American people hope their children go back home safely without injury or harm. The sentence "that the families of our military......." is modified by the factual 
verb 'know',(Quirk et al., 1985 : 1180-81),by which Bush signals his undoubted commitment to the factuality of his assertion that he is completely sure of the American love towards their soldiers. Bush's saying can be paraphrased, as (Saeed, 1997: 125) said, into "to the best of my knowledge I know that the families........".

\section{Text (3)}

George W. Bush, America and the Middle East: Address in the United Arab Emirates, Abu Dhabi, United Arab Emirate, January 13, 2008 :

"The other major cause of instability is the extremists embodied by al Qaeda and its affiliates. On September 11, 2001, al Qaeda murdered nearly 3,000 people on America's home soil. Some of the victims that day were innocent Muslims. And since then, al Qaeda and its allies have killed many more Muslims here in the Middle East -- including women and children."

-Establishing the felicitous speech act of assertion:

1- Propositional content condition: Bush refers to the assertive fact that is familiar to the world which has witnessed the attack of September 11 in which 3000 innocent people were killed; some of the victims were Muslims.

2- Preparatory condition: Bush commits himself to the truth of his assertion about the above proposition on the basis of the check-list record of the victims which includes names of some American Muslim people. In this context, Bush appropriately informs the United Arab Emirates' audience of this fact.

3- Sincerity condition: Bush plainly believes what he asserts.

4- Essential condition: Bush's saying is counted as a realistic assertion since it is true that 'some of' the victims were Muslims and his assertion represents an actual state of affairs in the real world.

\section{-Pragmatic analysis}

In respect to pragmatic features, Bush uses these words to show his assertion about the real fact which was happened to 3000 innocent people who were brutally killed in the destruction of the world Trade Centre in September 11 by al-Qaeda extremists, and the authentic check-list of those victims which calculates 'some of' them as American Muslim people. In this context, the pronoun 'some' is used as an explicit assertive pronoun delivering the direct illocutionary force of assertion (Biberet al., 1999: 176; Leech et al., 2001: 479). 


\section{Text (4)}

Barack Obama, Ending Combat in Iraq: Remarks at the Disabled Veterans of America Conference, Atlanta, Georgia, August 2, 2010 : Today, Cory is at a VA hospital in Florida. And with the support of his family and VA staff, he's working hard every day to regain his strength. He's got to learn to speak all over again. He's grateful for the visits he's received from friends and supporters - including the Disabled American Veterans."

-Establishing the felicitous speech act of assertion:

1- Propositional content condition: Obama expresses his confident assertion by virtue of the logical necessity of the situation in which the sergeant Cory Remsburg was seriously injured in his brain and consequently he becomes unable to speak well, so he necessarily has to learn speaking from the beginning.

2- Preparatory condition: Obama's evidence for this truth is based on the VA hospital reports which confirm what Obama has asserted. Obama's utterance is appropriate in the context of utterance.

3- Sincerity condition: Obama positively believes what he asserts.

4- Essential condition: Obama's utterance is counted as a logical assertion in the sense that it is true and represents an actual state of affairs in which the sergeant Cory has actually got to learn from the beginning.

-Pragmatic analysis

Pragmatically, Obama, in Georgia 2010, utilizes these words to express explicitly the direct illocutionary force of assertion by the use of the declarative sentence. He asserts to his addressees the logical necessity of Cory's case after his injury, exactly in his brain, disabling Cory of being able to speak well. Therefore, he has to learn to speak all over again. The semi-modal 'has got to', like 'must', is manipulated to reveal a strong degree of assertion(Swan, 2005: 210). Obama's saying can be paraphrased into " that is necessary he has got to ......,"carrying the illocutionary force of assertion.

\section{Text (5)}

Barak Obama, a new beginning: speech at Cairo University, Cairo, Egypt, June 4, 2009:

"I rejected the view of some in the West that a woman who chooses to cover her hair is somehow less equal, but I do believe that a woman who is denied an education is denied equality."

-Establishing the felicitous speech act of assertion:

1- Propositional content condition: Obama expresses the emphasized assertion about the women's equality to be well educated in order to 
become an effective leader in Muslims countries, as soon as this right is denied, so this will be considered as inequality. He contradicts the previous view of some in the west who affirm that a woman who chooses to cover her hair is somehow of less equality.

2- Preparatory condition: Obama's evidence for the truth of women's equality occurs behind the real examples of educated women in Muslims countries who already took charge of many positions as leaders of their countries. He appropriately reminds his addressees in this context.

3- Sincerity condition: Obama believes very strongly what he asserts.

4- Essential condition: Obama's saying is considered as a very strong assertion which stems from his intellectual state for the actual representation in the real world of women's equality.

-Pragmatic analysis:

Pragmatically, these words are utilized by Obama to express the direct illocutionary force of assertion by means of the declarative sentence. Obama, in Cairo, Egypt 2009, refers very strongly to the idea that "a woman who is denied an education is denied equality." On the contrary, some western people think that a woman who wears veil is of less equality. Although the main verb 'believe' signals a strong assertion, Obama uses the emphatic auxiliary 'do' before the main verb to declare explicitly the emphasized assertion for his belief to deny the former ideas of western people and to remove any doubt about the ex-situation (Feigenbaum, 1985: 122).

\section{Text (6)}

Tony Blair, Speech to Chicago Council on Global Affairs, office of Tony Blair, Thursday, April 23, 2009:

"So: should we now revert to a more traditional foreign policy, less bold, more cautious; less idealistic, more pragmatic, more willing to tolerate the intolerable because of fear of the unpredictable consequences that intervention can bring?"

In this context a dual illocutionary force has been performed, directly and indirectly. The relative felicity conditions must be applied so as to clarify which one of the illocutionary forces in this context is well established to be primary (indirect) and which one is to be secondary (direct). Therefore, the two illocutionary acts are to be explained as follows: 


\begin{tabular}{|c|c|}
\hline $\begin{array}{c}\text { The felicity conditions for } \\
\text { questioning(Saeed, 1997: 213-4). }\end{array}$ & The felicity conditions for assertion \\
\hline $\begin{array}{l}\text { 1- Propositional content condition: Blair } \\
\text { expresses his queries about the attitude } \\
\text { towards the intervention against the } \\
\text { oppressive regime across the world which } \\
\text { is based on humanitarian crisis and } \\
\text { oppression, he asks the members of } \\
\text { Chicago council in addition to the } \\
\text { international community about the current } \\
\text { position that should be adopted against } \\
\text { extremist regime. } \\
\text { 2- Preparatory condition: Blair doesn't } \\
\text { know the answer of his question, and it is } \\
\text { not obvious to him and to his addressees } \\
\text { that the addressees will provide the } \\
\text { information, which he has asked at that } \\
\text { time, without being asked. } \\
\text { 3- Sincerity condition: Blair clearly } \\
\text { wants the answer of the present-day } \\
\text { stance that should be supported. } \\
\text { 4- Essential condition:Blair's utterance is } \\
\text { counted as an attempt to elicit the } \\
\text { information about the current position } \\
\text { from his addressees that should be taken } \\
\text { up towards the intervention that is } \\
\text { grounded on the humanitarian crisis or } \\
\text { oppression of civilian population. }\end{array}$ & $\begin{array}{l}\text { 1- Propositional content condition: Blair } \\
\text { expresses his tacit assertion for the } \\
\text { current attitude towards the interventions } \\
\text { forth sake of humanitarian oppression of } \\
\text { civilian people, he implicitly affirms that } \\
\text { "we shouldn't be a less bold, more } \\
\text { cautious,lessidealistic, more pragmatic, } \\
\text { more willing to tolerance the } \\
\text { intolerable"because of fear of the } \\
\text { unpredictable results that intervention can } \\
\text { bring. } \\
\text { 2- Preparatory condition: Blair's evidence } \\
\text { for his implicit assertion is derivedfrom the } \\
\text { global condition in which the struggle } \\
\text { against extremist regimes, groups and } \\
\text { organization become more dangerous and } \\
\text { require engagement of a different and } \\
\text { more comprehensive kind. What Blair } \\
\text { asserts is rhetorically suitable in this } \\
\text { context. } \\
\text { 3- Sincerity condition: Blair plainly believes } \\
\text { what he asserts. } \\
\text { becomesmore dangerous andwe shouldn't } \\
\text { the extremism wherever can be found. } \\
\text { since it is true that the world }\end{array}$ \\
\hline
\end{tabular}


According to the context of utterance, Blair intentionally flouts the preparatory, sincerity and essential conditions for the direct (secondary) illocutionary force of questioning, in the sense that he knows the answer of what he asks for intervention against oppressive regimes and terrorist groups which should be stronger than before, also he does not want the information, and finally he does not attempt to obtain the answer from his addressees. As a result, they become infelicitous for making the successful direct speech act of questioning which is typically made by an interrogative sentence. Then, what is contextually appropriate is the truth of the felicity conditions of indirect (primary) illocutionary force of assertion.

The indirect illocutionary force of assertion which is made by the interrogative sentences is conventionally acceptable due to the fact that it has a certain degree of conventional usage reinforced by the rising-tone of uttering the rhetorical question.

In this point, Blair intends his utterance to be as an indirect illocutionary force of assertion made by means of the interrogative sentence, he implicitly asserts, to the Chicago council in his office 2009, the need of holding the same strategy which he affirms ten years ago that the intervention based on humanitarian crisis or oppression of civilian people is justified and morally necessary. Therefore, he believes that the position should not waver and should not be less bold, more cautious, and more tolerant because of fear of the unexpected consequences of that intervention. Blair uses the rhetorical question to express a strong assertion about the current position that should be held. Blair's expression can be paraphrased into "now, we should not revert to a more traditional foreign policy, less bold, more

\section{Text (7)}

Tony Blair, a common word between us and you: a global agenda for change,

Washington DC, Georgetown University, October 7, 2009:

"Love your God; love your neighbour as yourself. These simple admonitions are the guiding light of our faith. They give us the possibility of 'A Common Word.' When we lose our way, Christians or Muslims, this is the light by which we re-discover our true path. So: understand each other, respect each other, act with each other; and in doing so, show why humanity is not made poorer by faith, but immeasurably enriched."

This context reveals that two illocutionary forces, direct and indirect, have been performed, and in order to know which one is more 
contextually apt. Searle's felicity conditions must be applied, so that the felicity conditions for both illocutionary acts can be as follows:

\begin{tabular}{|c|c|}
\hline $\begin{array}{l}\text { The felicity conditions for ordering } \\
\text { (Searle, 1979: 44) }\end{array}$ & The felicity conditions for assertion \\
\hline $\begin{array}{l}\text { 1- Propositional content condition:Blair } \\
\text { predicates that Muslim and Christian } \\
\text { communities will understand, respect and } \\
\text { act with each other so as to show people } \\
\text { the strength of faith which is infinite. } \\
\text { 2- Preparatory condition: Blair believes } \\
\text { that his addressees are able to do what he } \\
\text { orders them. His authority permits him to } \\
\text { make his order since he is superior to } \\
\text { them. } \\
\text { 3- Sincerity condition: Blair believes that } \\
\text { what he orders them must be done. } \\
\text { 4- Essential condition: Blair's utterance is } \\
\text { counted as an expression of order in the } \\
\text { sense that he attempts to get the Muslim } \\
\text { and Christian communities not merely in } \\
\text { America but in all over the world to } \\
\text { understand, respect and act with each } \\
\text { other to show the richness of humanity of } \\
\text { boundless faith. }\end{array}$ & $\begin{array}{l}\text { 1- Propositional content condition:Blair } \\
\text { expresses his implicit assertion about the } \\
\text { fact that he hopes to be fulfilled, now and } \\
\text { in the future, of which the two large } \\
\text { communities, Muslims and Christians, } \\
\text { have to understand, respect and act with } \\
\text { each other in order to express human } \\
\text { faith. } \\
\text { 2- Preparatory condition: Blair's evidence } \\
\text { of his implied assertion is rooted in the } \\
\text { need of humanity to work with each other } \\
\text { to face the violence and extremism of the } \\
\text { terrorists around the world. Blair's } \\
\text { assertion is properly convenient in this } \\
\text { context. } \\
\text { Sincerity condition: Blair clearly believes } \\
\text { what he implicitly asserts. } \\
\text { 4- Essential condition: Blair intends his } \\
\text { utterance to be counted as an implicit } \\
\text { assertion that is realized contextually and } \\
\text { that represents an actual state of affairs in } \\
\text { the sense that it is true that there is a } \\
\text { necessary need for Muslimand Christian } \\
\text { communities in all over the world to } \\
\text { understand, respect and act with each } \\
\text { other to show the immeasurable faith of } \\
\text { humanity. }\end{array}$ \\
\hline
\end{tabular}

The context in which Blair says his utterance identifies the fact of the felicity conditions of the indirect (primary) illocutionary act of assertion, due to the truth that Blair intentionally flouts the sincerity and essential conditions of the direct (secondary) illocutionary act of directing (ordering), i.e. they become infelicitous for order. Blair does not want his order to be done in terms of obligation. In addition, he does not attempt to make his addressees understand, respect and act with each other as an obliged order for them to be followed. Therefore, his utterance is not counted as an expression of order. As a result, the felicitous or successful direct speech act of directive (ordering), which is typically made by an imperative sentence, is not fulfilled and established.

This indirect illocutionary force of assertion which is made by the imperative sentence has a certain degree of conventional usage and seems more acceptable in this context, since it is supported here by the falling-tone which contextually conveys the meaning of assertion rather 
than the meaning of order (command) which is also made by the fallingtone (O'Conner, 1980: 124).

Hence, this saying is intended by Blair to express the indirect illocutionary force of assertion by the use of an imperative sentence where he asserts, in Washington 2009, his hope and wish that all people in the world understand, respect and act with each other, Muslims and Christians, so as to show the world the human richness of immeasurable faith and human love of peace. Blair utterance can be paraphrased into "I hope that you understand each other, I hope that you respect each other, and I hope that you act with each other; and in doing so, show why......

\subsection{Results}

1- This study formulates a model for both direct and indirect speech act based on Searle's speech act theory, supported by Leech's speech situation. This answersquestion NO. (1).

2- This study conducts an appropriate felicity conditions for the speech act of assertion. This answers question NO. (2).

3 - In political texts, the direct and indirect speech act of Assertion can be fruitfully applied to express the speaker's feeling to convey the meaning of assertion. This answers question NO. (3).

4- The direct speech act of assertion is typically realized by the declarative sentence type. This answer question NO. (4)

5- The indirect speech of assertion can sometimes be realized through the use of interrogative and imperative sentences uttered with the appropriate intonation in political texts. This answer question NO. (5).

\section{Open questions:}

1- Can researchers analyse political speeches in terms of philosophical, cognitive and linguistic point of view?

2- What are the syntactic and semantic constructions of the speech act of assertion.

3- Would a contrastive study of assertion be interesting?

4- How can we differentiate between the'epistemic modal verbs' in their secondary functions as an assertion or certainty, and between the 'deontic modal verbs' in their primary functions which make, for example, the speech act of obligation, permission, threaten, request, etc.?

5- What are the cognitive notions which have a close relation to the concept of assertion?

6- Is it possible for the syllabus designers to encode assertive verbs in textbooks? 


\section{References:}

1) Akmajian, A., Demers, R.A., Frame, A.K. and Harnish, R.M. (2001).

Linguistics: An Introduction to Language and Communication. London: The MIT Press.

2) Austin, J.L. (1962). How to Do Things with Words. Oxford: Oxford University Press.

3) Barak Obama, a new beginning: Speech at Cairo University, Cairo, Egypt, June, 4, 2009. Retrieved from http://www.americanrhetoric.com/speeches/barackobama/barackobamacairo university.htm.

4) Barack Obama, Ending Combat in Iraq: Remarks at the Disabled Veterans of America Conference, Atlanta, Georgia, August 2, 2010, http://www.presidentialrhetoric.com/speeches/08.02.10.html

5) Biber, D., Johansson, S., Leech, G., Conrad, S. and Finegan, E. (1999). Longman Grammar of Spoken and Written English. China: Longman.

6) Cruse, A. (2000). Meaning in Language. Oxford: Oxford University press.

7) . (2006). A Glossary of Semantics and Pragmatics. Edinburgh: Edinburgh University Press.

8) Crystal, D. (2003). A Dictionary of Linguistics and Phonetics. $5^{\text {th }}$ ed. London: Blackwell Publishing Ltd.

9) Downing, A. and Locke, P. (2006). $2^{\text {nd }}$ ed. English Grammar: A University Course .New York: Routledge.

10) George. W. Bush, America and the Middle East: Address in the United Arab Emirates, Abu Dhabi, United Arab Emirate, http://www.presidentialrhetoric.com/speeches/01.13.08.html

11) George. W. Bush, War Message, Washington, DC, March 19, 2003. Retrieved from http:// www.presidentialrhetoric.com/speeches/03.19.03.html.

12) Grundy, P. (2000). Doing Pragmatics. $2^{\text {nd }}$ ed. London: Arnold.

13) Horn, L. and Warq, G. (ed) (2004). The Handbook of Pragmatics. United kingdom: Blackwell publishing Ltd.

14) Huang, Y. (2007). Pragmatics. Oxford: Oxford University Press.

15) Hurford, J. R., Heasley, B. and Smith, M, B. (2007). A course book in Semantics. $2^{\text {nd }}$ ed. Cambridge: Cambridge University Press.

16) Jespersen, O. (1968). The philosophy of grammar. London: George Allen and

17) Unwin Ltd.

18) Feigenbaum, I. (1985). The Grammar Handbook. The United States of America: Oxford University Press.

19) Leech, G. (1983). Principles of Pragmatics. London: Longman.

20) _ (2001). An A-Z of English Grammar and Usage. London: Arnold.

21) Levinson, S. (1983). Pragmatics. Cambridge: Cambridge University Press.

22) Macmillian, (1964). The Key to English Verbs. New York: Macmillian Publishing Co. Ltd.

23) Mey, J. (1993). Pragmatics: An Introduction. Oxford: Blackwell Publishers.

24) Morgan, J.L. (1978). Two types of convention in indirect speech acts. In cole, P. (ed.) 261-80.

25) O'Conner, L.D. (1980). Better English Pronunciation. $2^{\text {nd }}$ ed. Cambridge: Cambridge University Press.

26) Pagin, P. (2007). "Assertion". [http://www.plato.stanford.edu/entries/assertion. htm.]. 
27) Palmer, F.R. (1981). Semantics. $2^{\text {nd }}$ ed. Cambridge: Cambridge University Press.

28) Quirk, R. Greebaum, S., Leech, G. and Svartvik, J. (1985). A

Comprehensive Grammar of the English Language. London: Longman Group Ltd.

29) Saeed, J. (1997). Semantics. Oxford: Blackwell Publishers.

30) Schiffer, S.R. (2002). Meaning. Oxford: Oxford at the Clarendon Press.

31) Searl, J.R. (1969). Speech Acts. London: Cambridge University Press.

32) . (1979). Expression and meaning. Cambridge : Cambridge University Press.

33) Swan, M. (2005). Practical English Usage. $3^{\mathrm{d}}$ ed. Oxford: Oxford University Press.

34) Tony Blair, a common word between us and you: a global agenda for change, Washington DC, Georgetown University, October 7, 2009. Retrieved from http://www.tonyblairoffice.org/speeches/entry/tony-blair-addresses-commonword-conference.

35) Tony Blair, Speech to Chicago Council on Global Affairs, office of Tony Blair, Thursday, April 23, 2009. Retrieved from http://www.tonyblairoffice.org/speeches/entry/tony-blair-speech-to-chicagocouncil-on-global-affairs.

36) Van Dijk, T.A. (1977). Text and context: Explorations in the semantics and Pragmatics of Discourse. London: Longman Group Ltd.

37) Verschueren, J. (1999). Understanding Pragmatics. London: Edward Arnold.

38) Yule, G. (1996). Pragmatics. Oxford: Oxford University Pres

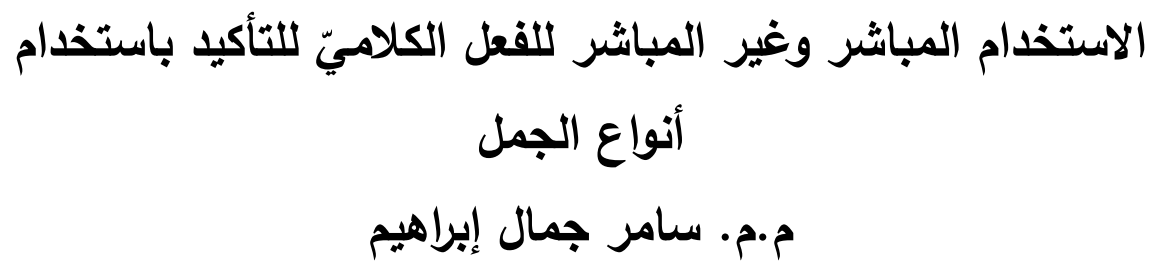

الملخص:

إنَّ معالجة أيّ نص، منل النص السياسي، بدون الأخذ بالحسبان النظرية التداولية (pragmatic theory) يشكل

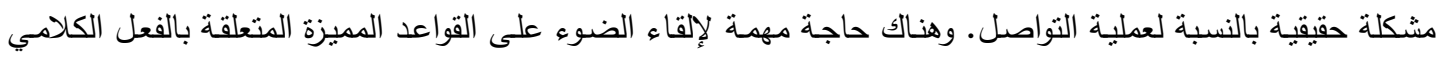

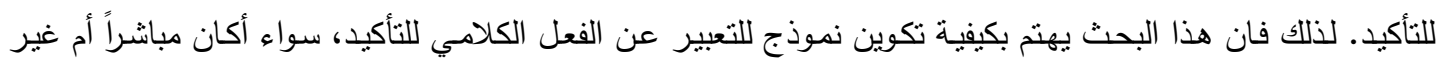

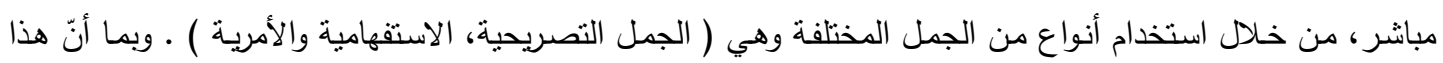

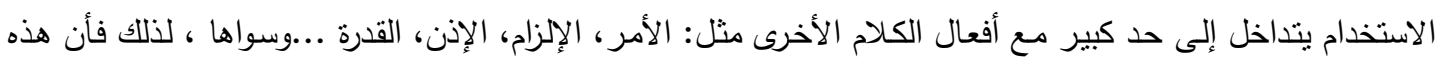

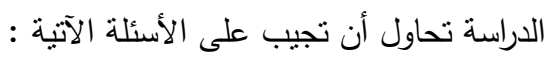

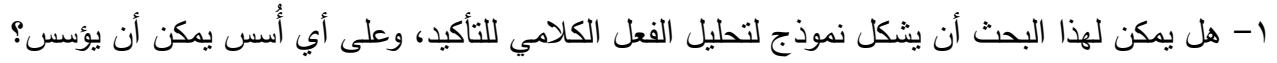

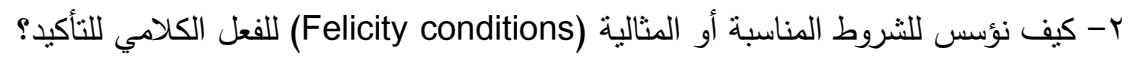

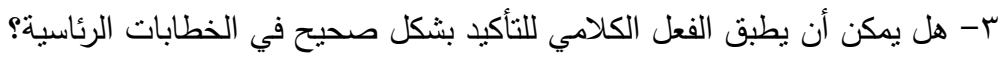

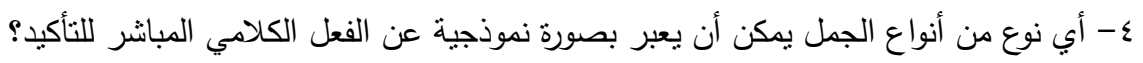

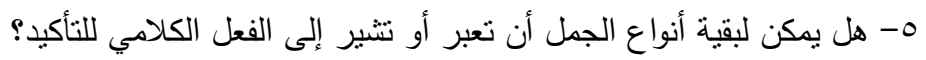

